\title{
Krátký test zrakově-prostorové paměti: normativní data a nové indexy učení
}

\author{
Filip Havlik, Josef Mana, Hana Georgi, Ondřej Bezdíček
}

Neuropsychologie v České republice se postupně stále více stává kompetitivním oborem i na mezinárodní úrovni (Štěpánková Georgi, 2018). Dostupnost standardizovaných neuropsychologických testových metod je však oproti zahraničí výrazně omezená. To limituje jak další rozvoj oboru, tak poskytování péče v rámci tzv. přístupu založeného na důkazech. Jednou z chybějících metod v české praxi je i Krátký test zrakově-prostorové paměti - revize (BVMT$\mathrm{R})$.

BVMT-R je test zrakové a prostorové deklarativní paměti, jehož principem je ve třech po sobě jdoucích pokusech zapamatovat si a nakreslit šest obrazců prezentovaných na podnětovém archu v matici $2 \times 3$. K zapamatování si obrazců má testovaný vždy 10 sekund. Kromě těchto tři pokusů zahrnuje BVMT-R také oddálené vybavení (DR), rekognici a kopii. Kromě rekognice jsou jednotlivé pokusy hodnoceny $\mathrm{z}$ hlediska přesnosti a umístění každého z šesti obrazců, kdy lze v každém pokusu získat $0-12$ bodů. Rekognice je ve formátu nuceného výběru (ano/ne) a maximálně dosažitelným skórem je opět 12 bodů (Benedict, 1997).

Tento test je celosvětově jedním z nejpoužívanějších měřítek zrakově-prostorové paměti a oproti podobným testům, např́klad testu Reyovy-Osterriethovy komplexní figury (Meyers \& Meyers, 1995), disponuje díky třem pokusům také možností výpočtu indexů učení. $\mathrm{Z}$ tohoto důvodu jsme se rozhodli pro vytvoření normativních dat a zpř́stupnit tak BVMT-R české psychologické obci. Naše úsilí vyústilo v normativní datový soubor o velikosti 920 probandů ve věku od 17 do 95 let.

Dále jsme díky aplikaci postupů zavedených k výpočtu indexu učení například v Pamětovém testu učení (Bezdicek et al., 2014) identifikovali nový index učení s vyšší diskriminační přesností než index uvedený v oficiální př́ručce BVMT-R. Bohužel se nám nepodařilo získat od majitele práv souhlas s vydáním plnohodnotné verze zahrnující i český manuál, nicméně BVMT-R lze zakoupit prostřednictvím stránek PAR, Inc. (https://www.parinc.com/Products/Pkey/30) a využít česká normativní data, která jsou $\mathrm{k}$ dispozici v našem nedávno vydaném článku (Havlík et al., 2020). I přes tato omezení věříme, že je BVMT-R důležitým nástrojem použitelným v běžné psychologické praxi. 


\section{Reference}

Benedict, R. H. B. (1997). Brief Visuospatial Memory Test-Revised: Professional manual. PAR.

Bezdicek, O., Stepankova, H., Moták, L., Axelrod, B. N., Woodard, J. L., Preiss, M., Nikolai, T., Růžička, E., \& Poreh, A. (2014). Czech version of Rey Auditory Verbal Learning test: Normative data. Aging, Neuropsychology, and Cognition, 21(6), 693-721. https://doi.org/10.1080/13825585.2013.865699

Havlík, F., Mana, J., Dušek, P., Jech, R., Růžička, E., Kopeček, M., Georgi, H., \& Bezdicek, O. (2020). Brief Visuospatial Memory Test-Revised: normative data and clinical utility of learning indices in Parkinson's disease. Journal of Clinical and Experimental Neuropsychology, 1-12. https://doi.org/10.1080/13803395.2020.1845303

Meyers, J. E., \& Meyers, K. R. (1995). Rey complex figure test and recognition trial: Professional manual. Psychological Assessment Resources.

Štěpánková Georgi, H. (2018). Neuropsychologie v ČR v roce 2018. E-psychologie, 12(2), 61-63. https://e-psycholog.eu/pdf/stepankova-georgi-zp.pdf

\section{O autorech}

Mgr. Filip Havlík, výzkumný pracovník na Pražské vysoké škole psychosociálních studií, doktorand oboru Neurovědy na 1. lékařské fakultě Univerzity Karlovy.

Kontaktní údaje: filip.havlik.kv@gmail.com

Mgr. Josef Mana, výzkumný pracovník na Pražské vysoké škole psychosociálních studií, doktorand oboru Neurovědy na 1. lékařské fakultě Univerzity Karlovy.

Kontaktní údaje: ironmana@email.cz

PhDr. Hana Georgi, Ph.D., prorektorka pro vědu a výzkum na Pražské vysoké škole psychosociálních studií.

Kontaktní údaje: hana.georgi@pvsps.cz

doc. Mgr. Ondřej Bezdíček, Ph.D., docent lékařské psychologie na Univerzitě Karlově, pedagogický pracovník na Pražské vysoké škole psychosociálních studií, psycholog a výzkumný pracovník Neurologické kliniky 1. LF UK a VFN v Praze.

Kontaktní údaje: ondrej.bezdicek@lf1.cuni.cz

Havlík, F., Mana, J., Georgi, H., \& Bezdíček, O. (2021). Krátký test zrakově-prostorové paměti: normativní data a nové indexy učení. E-psychologie, 15(1), 92-93. https://doi.org/10.29364/epsy.395 